\title{
American Regionalism and Brazilian Diplomatic Discourse (1946-2019)
}

\author{
Felipe Ferreira de Oliveira Rocha* \\ Marcelo de Almeida Medeiros**
}

\begin{abstract}
In this article, we analyse the content of the speeches delivered by Brazilian Presidents, Foreign Ministers and Ambassadors at annual Ordinary Sessions of the United Nations General Assembly in the period between 1946 and 2019. Our primary objective is to find out how often and under what circumstances Brazilian diplomats mentioned the subject of American regionalism and whether the mention was made in reference to specific projects or to abstract concepts of regional integration and cooperation. Based on this analysis, we highlight the great deal of importance that was given to MERCOSUR - and, to a lesser extent, UNASUR - to the detriment of other regional integration projects, as well as the preference, by Brazilian diplomats, for a flexible, low-profile, abstract and low-cost discursive approach. In short, we found that cooperation and integration have frequently been discussed, although little attention has been devoted to the limits and possibilities of each project under construction.
\end{abstract}

Keywords: regional integration; Brazilian Foreign Policy; Foreign Policy Analysis; content analysis; diplomacy; United Nations.

\section{Introduction}

How often and by using what rhetorical frameworks did Brazilian diplomatic actors (both professional and presidential) make space in their speeches at the United Nations General Assembly to draw attention to regionalization efforts in the American continent between 1946 and 2019?

The vast evidence on American regionalism points to a contradictory pattern, in which minimalist institutional efforts co-exist with a kind of maximalist rhetorical ceremonialism. This, in turn, seems to produce a somewhat chimerical phenomenon, whereby political leaders end up delaying (if not abandoning) efforts to strengthen regional institutions, thus producing a huge gap between what they say can be done to support the region and what they actually choose to do (Montecinos 1996; Dabène 2009; Medeiros and Dri 2013; Jenne 2013; Jenne et al 2017).

\footnotetext{
* Federal University of Pernambuco (UFPE), Recife-PE, Brazil; rocha.felipeferreira@gmail.com. ORCID iD 0000-0002-9978-5703.

** Federal University of Pernambuco (UFPE), Recife-PE, Brazil; mam14@uol.com.br. ORCID iD 0000-00018385-0358.
} 
Regardless of the social and political functions that a discourse performs in and of itself - be it to build realities or to mask certain interests, in the relevant literature, it has now become commonplace to say that American regionalism is (merely) rhetorical. However, while this rhetorical dimension of regional projects is widely recognised and emphasised, very few research enterprises have seriously faced it and dissected it analytically in terms of collecting, organising, analysing, and inferring the rhetorical structure of each actor. Certainly, albeit rare, some excellent works address these questions and have helped to gradually shape an agenda that investigates the discursive constellations of American regionalism through a combination of quantitative and/or qualitative techniques (Fitjar 2005; Vilela and Neiva 2011; Meunier and Medeiros 2013; Jenne et al 2017).

Building on the efforts of the aforementioned authors, this article seeks to identify how often and under what circumstances Brazilian diplomacy mentioned American regionalism in multilateral settings. To this end, we conducted content analysis in speeches delivered by Presidents, Foreign Ministers and Ambassadors at the opening of the annual Ordinary Sessions of the United Nations General Assembly between 1946 and 2019. The choice of Brazil as the object of study is justified by the historical weight that the country has attributed to speeches within its conceptual frameworks, using them to support international action via soft power and/or consensual hegemony (Arbilla 2000; Burges 2006, 2008; Wehner 2015; Mares and Trinkunas 2016).

Despite having its own limitations, analysing Brazilian speeches at the United Nations (UN) is a fundamental task for all those interested in understanding, in depth, the most significant guidelines of the Brazilian Foreign Policy (BFP). As former-Foreign Secretary Celso Amorim stated when presenting the second edition of the book Brazil at the United Nations, pronouncements at the opening of the UN General Assembly are of central importance for Brazilian diplomacy, as they establish major public milestones for BFP (as well as concepts, orientations and guidelines) and create expectations for subsequent multilateral engagements (Corrêa 2012: 14). In this context, we analysed 75 speeches over a period of 73 years, with an average of 3053 words per speech.

With the exception of this introduction and the closing remarks, the article is divided in four parts. Firstly, we provide a historical and theoretical overview of regionalism in the Americas, covering the concepts and theories most used in that specialized literature to account for the rise and fall of American regional projects and discuss their historical and practical limits. In the following section, we place this discussion within the more specific context of BFP to explain the role of ideational and discursive factors within Brazil's international strategy in order to highlight the importance of analysing Brazilian discourse in diverse institutional settings.

In the third section, we explain the details of the methodological approach that guided the analysis, as well as how it led us to our conclusions. That way, we offer assurances regarding the reliability of the article and replicability of the research process, an essential dimension of the social sciences, especially when techniques like content analysis are utilized. Finally, we present the findings of this article, demonstrate its contributions to the existing literature, and also identify their limitations. 


\section{Regionalism in the Americas}

Before we begin the theoretical discussions of this paper, for clarity purposes, it is crucial to define what is hereby meant by 'American regionalism.' We pretty much follow the working definition of Hurrell (1992) with regards to 'America' or the 'American continent,' referring to the broad political, geographical, cultural, economic, and even the imagined portions of the territories 'encompassing Latin and Central America, the United States and Canada' (Hurrell 1992: 121). Likewise, we adopt a wide definition of regionalism that includes each effort of cooperation and integration, be it regional, hemispheric, South American, or Latin American. Consequently, for the purposes of this analysis, American regionalism refers to what Hurrell (1992) identifies as being the two routes through which regional blocs have been established in the continent: uncoerced regionalism (without the United States) and hegemonic regionalism (with the USA).

Theories about regionalisms can be grouped into three main categories: the systemic, the regional and the domestic. The first emphasises structural conditions in the international system and draws from Neo-Realist and Complex Interdependence paradigms as their main sources of inspiration. By contrast, analysis that are predominantly regional tend to draw on theories such as Neofunctionalism, Liberal Institutionalism and Constructivism. Finally, explanations based mainly on a domestic focus form a third group, which works with concepts such as state coherence, regime type, degree of democratization, and convergence (Hurrell and Fawcett 1998).

However, in the case of American regionalism, theoretical fluency alone is insufficient for producing valid explanations and analyses; it is also necessary to take into account the historical peculiarities of regionalization in the continent, its characteristics and institutional initiatives (Dabène 2009).

In this respect, although enthusiasm for regional integration in the American continent existed in an embryonic way since at least the independence period, only in the 1960s it started to be institutionalised. At this time, both an autonomist vision, influenced by Simón Bolívar, and a hemispheric one, based on the Monroe doctrine and on pan-Americanism, gradually emerged (Dabène 2009; Tussie 2009; Riggirozzi 2012; Jenne 2013). However, these pioneering conceptions of regionalism were more associated with the idea of political cooperation/integration rather than the with idea of institutional bodies to promote competitive economic advantages.

Formally, the first wave of regionalization projects in the continent with a clear economic-commercial dimension began in the 1960s. The main characteristics of the socalled closed, old or hacia adentro (inward) regionalism were the pursuit of development through a protectionist model of industrialization, based on the diagnosis that the region needed to react to systemic trade constraints in order to strengthen itself in a collective and sustainable way (Malamud and Gardini 2012; Riggirozzi 2012; Gardini 2015; BriceñoRuiz 2018).

In the midst of the Cold War, the USA distanced itself from Latin American issues; this enabled the rise of autonomist theories grouped under the Economic Commission for Latin America (CEPAL), which saw the substitution of imports as a way of stimulating 
industrialization and development as a consequence thereof. Arrangements such as the Latin American Free Trade Association (ALALC), the Caribbean Free Trade Association (CARIFTA), the Central American Common Market (MCCA), and the Andean Pact are examples of this line of thought (Dabène 2009; Amado and Mollo 2004).

Despite this effervescence, the 1970s and 1980s were marked by crisis and inertia. Few new regional arrangements were created at that time, and the existing ones were not strengthened. Meanwhile, the developmental model faced insurmountable challenges as the Latin American economy as a whole was hit with stagnation, fiscal deficits, and high inflation rates (Dabène 2009).

From the 1990s on, however, a new wave of regionalism flourished. This regionalism has been described as new, open and hacia afuera (outward oriented). At its core were the guiding principles of economic liberalisation prescribed by the International Monetary Fund (IMF) and based on the idea that regional arrangements should be a means of strengthening international trade rather than protecting or withdrawing from it (Malamud and Gardini 2012; Gardini 2015; Briceño-Ruiz 2018).

This period was also marked by the region's slow and unfinished democratic transition. Regional projects came to be seen as another way of expanding plurality and building bonds of trust between countries. Projects such as the Common Market of the South (MERCOSUR), negotiations for a Free Trade Area of the Americas and the North American Free Trade Agreement (NAFTA) emerged from this context (Hurrell 1992; Dabène 2009).

Over the course of the 2000s, although regional experiences maintained their original aims, they could no longer be explained only through the lens of open regionalism. Many of the regional blocs expanded their scope of action beyond trade to include social, cultural and political issues. Some paradigmatic examples were the inclusion of the cultural dimension within the scope of MERCOSUR, the creation (and later disbanding) of the Union of South American Nations (UNASUR), and the radical critique represented by the Bolivarian Alliance for the Peoples of Our America (ALBA). To explain these new regional arrangements, authors have proposed concepts such as 'post-liberal' and 'post-hegemonic regionalism' (MacDonald and Rückert 2009; Malamud and Gardini 2012; Riggirozzi 2012; Riggirozzi and Tussie 2012; Legler 2013; Gardini 2015; Briceño-Ruiz 2018).

The concept of post-liberal regionalism concerns the efforts of Latin American regional projects at the beginning of the $21^{\text {st }}$ century to expand and go beyond liberal models and trade liberalisation. In these projects, political and logistical dimensions were more fundamental than mere economic exchanges, and strong and development-oriented states were seen as decisive. In a way, this concept reflects the discourse of UNASUR and ALBA. By contrast, the concept of post-hegemonic regionalism, albeit similar, theorizes the behaviour of Latin American states through the context of American hegemony, in which proponents' claim suffered spasms and declined, both in the region and in the world (albeit gradual) (MacDonald and Rückert 2009; Riggirozzi 2012; Riggirozzi and Tussie 2012; Legler 2013).

From the 2010s on, some authors began to criticize the post-liberal explanation and argued that it was unable to account for the diverse features of American regionalism. 
On the one hand, most of the existing blocs remained in operation, even though some had entered a state of inertia. On the other hand, the formalization of the Pacific Alliance showed that the model of open regionalism was still capable of exerting significant influence on the continent (Nolte and Comini 2016; Briceño-Ruiz 2018). As anomalous as it may sound, the creation of the Fórum para o Progresso e Desenvolvimento da América do Sul (Forum for the Progress and Development of South America, PROSUL) shows how resilient is neoliberal regionalism in the American continent.

In response to that criticism, Gardini (2015), for example, has proposed the concept of modular regionalism as an alternative theoretical-analytical explanation. Recalling that regionalism is also a form of multilateralism, the author contributes to the theoretical debate by suggesting that analysis be made on the basis of contextual adjustments and on the identification of where, whom and how to act (Gardini 2015). More than just identifying state rhetoric, according to him, it would be necessary to see regionalism as modular and dependent, based on the adjustments that the players involved make when deciding for or against cooperating in certain institutional spheres.

However, as important as concepts and typologies may sound, understanding American regionalism depends, in a way, on its own machinery, characteristics and dynamics. In this regard, Dabène (2009) lists some peculiar features of the American context, such as the fact that integration is not motivated by overriding security and defence considerations (due to the history of relative continental peace), the disinterest of states in ceding sovereignty, the multidimensionality of cooperation initiatives, and the resilience of projects. In short:

Latin America's experience with integration can be characterized by several factors that have not been sufficiently addressed by the literature: imagined political integration long remaining essentially rhetorical; economic, social, or cultural integration from below despite many obstacles; integration from above launched at some critical junctures; resilience and consistency of the institutional arrangements despite instability and crises; mismatch between scope and level of integration; and poor policy outcomes (Dabène 2009: 24).

It is also necessary to note how important internal dynamics are in a continent where regionalism has fragmented, under the weight of an asymmetric correlation of forces, into two major trends, the hemispheric and the regional, and even with significant differences and fractures within these two groups (Hurrell 1992; Phillips 2003).

Roughly speaking, the search for liberalisation, disciplinarisation and trade expansion supported by a stable and democratic political framework that ensures predictability for possible business disputes and tensions is characteristic of hemispheric regionalism. By contrast, Latin American regionalism prioritises other interests, such as the pursuit of development, autonomy, security, state strengthening, and increasing the bargaining power of countries (Phillips 2003; Tussie 2009; Long 2015). 
Along similar lines, Briceño-Ruiz (2018) argues that even if the region formally adopts the American concept of the western hemisphere, in practice, fragmentation produces a dynamic whereby countries cluster into three groups: those who practice an acquiescent or peripheral regionalism (represented by the Pacific Alliance), those who adopt an autonomist model (represented by MERCOSUR and UNASUR), and those who have opted for counter-hegemonic struggle (as symbolised by ALBA).

Malamud and Gardini (2012: 118) argue, for instance, that the segmentation and overlapping of regional arrangements have led to exhaustion, stunted progress and to a 'spinning around without deepening or going back to standard cooperation arrangements.' For them, Latin American regionalism is over-inflated and lacks a minimal common denominator, in addition to presenting the following limitations: a) The region is unable to provide the goods it needs for itself, revealing more commercial competition than complementarity); b) Absence of a paymaster; c) Focus on specific issues instead of broad identity constructions, presenting itself as 'more issue-based than region-based'; d) Propensity towards bilateralism and multilateralism, instead of regionalism.

Nolte and Comini (2016: 550), however, disagree with this view. When studying the behaviour of countries like Brazil and Argentina in UNASUR, they countered some of these criticisms, arguing that many of the limitations highlighted by scholars come from adopting the European case as a point of reference. For these authors, this is a wrong approach, since regional arrangements are not an end in themselves. Therefore,

$[\mathrm{O}]$ ne should take seriously the statements, declarations, and proposals of the actors involved in regional projects, and furthermore should not ask for the delivery of goods never promised by those participating in them - in our case, Latin American governments (Nolte and Comini 2016: 550).

This observation is key for the purposes of this article. It is necessary to remember that 'regionalism is both policy and project' (Tussie 2009: 169). Leaving speeches, symbols, perceptions, expectations, identities, worldviews and all sorts of ideational factors aside is to discard a range of political explanations. After all, Montecinos (1996) has already identified that, in Latin America, regionalism also fulfils ceremonial, symbolic and rhetorical functions.

In that sense, we believe that the concept of declaratory regionalism is useful (Jenne 2013; Jenne et al 2017). According to Jenne, there is an important gap in Latin American arrangements in the sense that decision makers appear to have established a logic of minimalist action and maximalist discourse, regardless of the constraints that emerge from the gap between speaking and doing.

In fact, Jenne (2013) first argues that this discrepancy between promise and implementation should not be viewed by analysts as merely cheap talk, but rather as an effort taken by decision makers to keep regionalism on standby. This argument was then empirically tested in a joint publication by Jenne, Schenoni and Urdinez (2017). Among various contributions to the debate, the article opened up greater space for focussing 
systematically on studying political actors' discursive emphases and silences in their regional narratives. Inspired by this particular piece and by similar literature, we will offer an analysis focused on the pronouncements made by Brazilian diplomatic actors. There are multiple reasons for conducting this empirical investigation specifically directed on the Brazilian case, which we will present below.

\section{BFP and American regionalism}

Historically, Brazilian decision makers have developed pendular relationships with the Latin American region. At times, actions and discourses of distancing and rejection have predominated; at others the Brazilian state has moved closer for purposes of cooperation and the construction of common regional activity (Briceño-Ruiz and Puntigliano 2017). Indeed, Brazil has assumed varied (and even overlapping) regional identities and horizons which, in certain aspects, served as an explanatory basis and even as a justification for maintaining pendular relations with its neighbours. At first, the independent and conservative Brazilian empire placed itself in a position of antithesis when it found itself surrounded by revolutionary republics. Brazilian decision makers, therefore, preferred to adopt a conceptual framework closer to the European than to the American model (Arbilla 2000; Santos 2005; Couto 2007).

With the rise of the republican movement, whose motto sought to emphasize being American and being in America, paths of Brazilian identity began to be modulated (at least rhetorically) by a Pan-American worldview, though the country remained quite distant from its geographic neighbours (Pinheiro 2004; Santos 2005; Couto 2007; Bethell 2009).

Factors such as the reduced presence of the USA in the context of the Cold War, the rise of Latin American autonomist and developmental thinking (institutionally cultivated by CEPAL), the emergence of regional blocs, and the formation of cooperative arrangements in Latin America helped explain why Brazil's identity gradually moved further from the Pan-American and closer to the Latin American (Amado and Mollo 2004; Santos 2005; Couto 2007; Spektor 2010). This Latin horizon competed, and continues to compete, for space with the previous labels and others that, under certain circumstances, have emerged as more politically appropriate, such as the concept of South America (Spektor 2010).

The role and perception of Brazil varies according to the particular themes in question. Prospects for power, diplomatic action, discursive positioning, labels and regional horizons depend on a mixture of domestic, international and economic factors; these, in turn, can create a matrix of arrangements with countries both closer to and further from Brazil's sphere of influence (Saraiva 2014; Gardini and Almeida 2017).

As a matter of fact, such an inherently particular identity both helps and harms the country's image in its regional and global initiatives. It should be noted that, globally, the path taken by the Brazilian state when pursuing international participation as an emerging power has also been characterised by pendular movements of rise and decline (Cervo 
and Lessa 2014). In a way, this volatility can be explained by both the lack of a strategy to establish deep, compensatory regional institutional ties (carrots) and by the capacity to threaten the use of brute force as a deterrent (sticks) (Burges 2006, 2008, 2009).

Not being able nor willing to play the role of paymaster or regional hegemon, Brazil stands out as the only major current example of a power that has sought to rise only through soft power, with the accumulation of prestige and influence, without resorting to hard power through an increase in military power and capacity (Burges 2006; Mares and Trinkunas 2016).

It is not surprising, therefore, that analysing the rhetoric, arguments, narratives, worldviews and ambitions of decision makers should be so essential for understanding and explaining BFP actions and decisions (Burges 2008). Indeed, Stuenkel and Taylor (2015: 9) recall that 'a recurring and central theme is the importance of deeply held Brazilian convictions about the world order, and the manner by which these ideas about the world shape this important middle power's approach to liberal international norms and institutions.'

Of course, by defending the importance of analysing the themes emphasised in Brazilian diplomatic speeches, we do not intend to deny nor claim that Brazil is more or less successful in adopting the path of a 'smooth' power rise. This would depend on varying arrangements of different structural and cyclical forces in each institutional space. That is to say, by adopting consensual hegemony, Brazil is able to act easily in certain governance contexts and global regimes, yet it also ends up being constrained in its capacity to influence outcomes that are more dependent on military bellicosity and material power (Burges 2006; Mares and Trinkunas 2016).

Malamud (2011) provides clear examples of Brazil's limitations given that he highlights attempts to support the building of regional bases and alliances that turned out to be erratic and counterproductive. Regardless of whether the soft power strategy adopted by Brazil is fruitful or unsuccessful, it is indeed unique and needs to be evaluated in a critical way. In order to achieve this, however, we must understand how this strategy is articulated discursively. To this end, we aim to contribute to the discussion by providing empirical data that helps to understand how, when and to what extent Brazilian decision makers have chosen to give greater or lesser multilateral visibility to regional construction efforts.

We want to know whether or not Brazilian diplomats were willing to dedicate the precious minutes they have to speak at the annual Ordinary Sessions of the United Nations General Assembly to place regional issues on the global agenda, or whether they preferred to emphasize the specific agendas of BFP instead. In that sense, the article has more of an exploratory and descriptive than a conclusive nature, seeking to find patterns in the speeches analysed that highlight Brazilian particularities regarding its characterisation of Latin American regionalism within a global perspective. Thus, we aim to find out under what circumstances Brazilian diplomacy has emphasised American regionalism, to a greater or lesser extent. In this regard, the next section explains in detail the methodological approach we have adopted to arrive at the results presented subsequently. 


\section{Methodology}

In terms of our methodological approach, it is best to start the discussion by explaining which texts were used, and how they were collected and processed, that is, by outlining the key features of the material used. There were two main sources for the analysis. The first is a collection published by the Alexandre de Gusmão Foundation entitled Brazil at the United Nations (Corrêa 2012), a book which contains speeches ranging from the First Ordinary Session of the UN General Assembly to the Opening of the General Debate of the LXVI United Nations General Assembly from 1946 to 2011. The second source came from the library of the Presidency of the Republic and/or from the Itamaraty website that entails presidential speeches for the opening sessions of the UN General Assembly between 2012 to 2019.

All the texts collected were converted to simple text format (.txt). There was no need to perform any special treatment on them, since they were all editable. Graph 1 provides a general overview of who the speakers were.

Graph 1 - Speakers at the Annual Ordinary Sessions of the UN Assembly
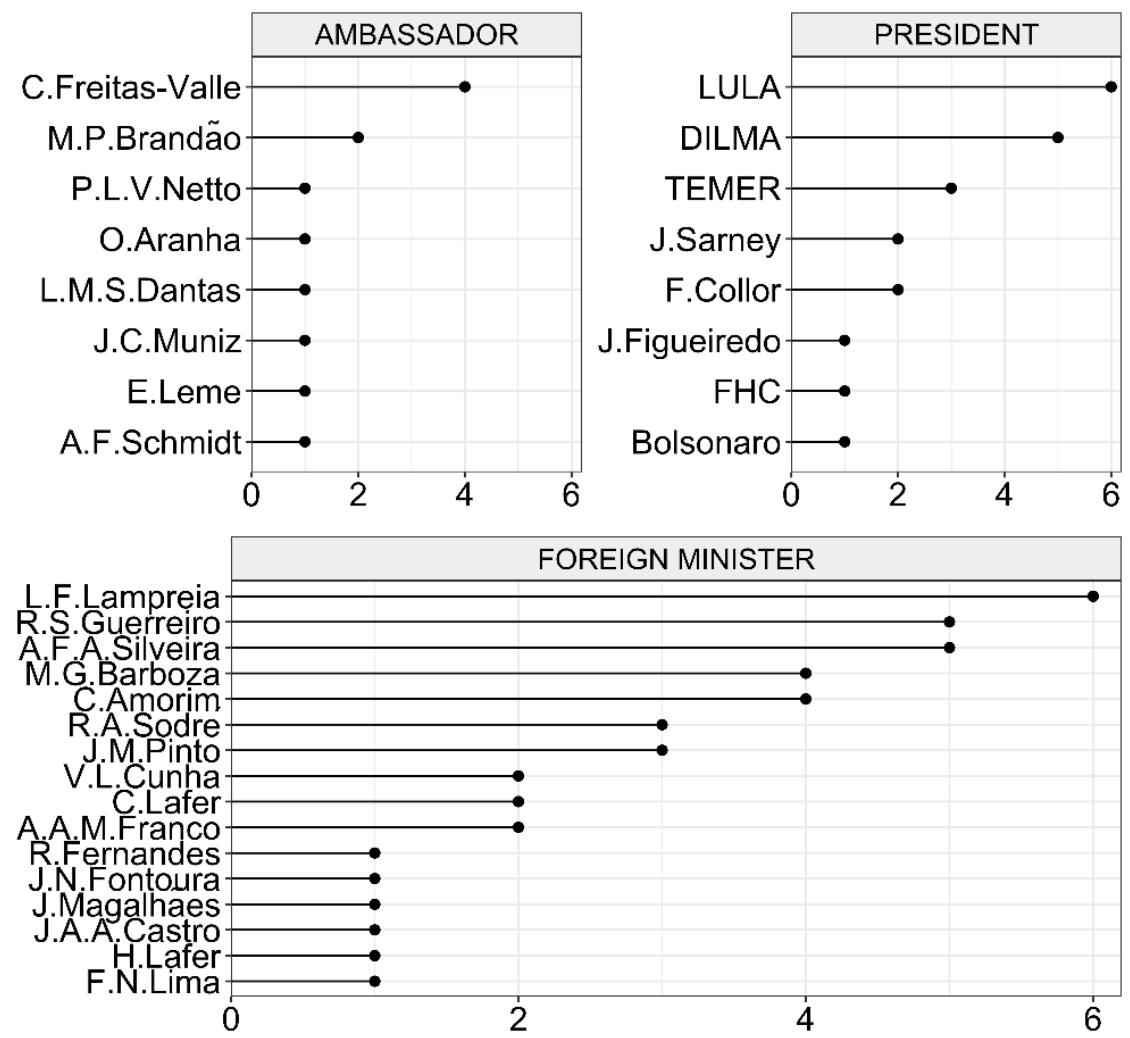

Source: Created by the authors. 
As seen in Graph 1 above, the main figures to deliver speeches at the annual Ordinary Sessions of the UN were professional diplomats (such as Foreign Secretaries and some Ambassadors). In fact, with the exception of Figueiredo, presidents only began to speak in this multilateral setting after Brazil's redemocratization. The most prominent among those were Ambassador Freitas-Valle, who spoke 4 times, Foreign Secretary Lampreia, who delivered 6 speeches, and President Lula, who also delivered 6 speeches.

To achieve the intended results, the method of content analysis was adopted. This is quantitative and based on a dictionary produced specifically for the purposes of this article (Weber 1990). We also applied qualitative and critical discourse analysis to complement our understanding of the context regarding the different regional projects discussed.

The dictionary created is divided into two main files. The first pursues the objective of measuring the depth with which each project was discussed by political actors. Therefore, we chose a clear, simple and precise definition, using the relevant acronym and full official name in Portuguese to account for the language in which the speeches were delivered. For the sake of space, the dictionary was not reproduced in its entirety here. However, like all the other files used in the research, they will be made available on open access platforms ${ }^{1}$.

Regarding this first dictionary, however, we would like to clarify that we measured the following projects: the Latin American Free Trade Association and Latin American Integration Association $\left(\mathrm{ALADI}^{*}\right){ }^{2}$ the Bolivarian Alliance for the Peoples of Our America and the Bolivarian Alternative for the Americas $\left(\mathrm{ALBA}^{*}\right)$; the Andean Pact and the Andean Community of Nations $\left(\mathrm{CAN}^{\star}\right)$; the Caribbean Community (CARICOM) and the Economic Commission for Latin America (CEPAL); the Free Trade Area of the Americas (FTAA); the Inter-American Development Bank (IDB) and the Inter-American Court and Commission on Human Rights (ISHR ${ }^{\star}$ ); the Common Market of the South (MERCOSUR); the North American Free Trade Agreement (NAFTA); the Organization of American States (OAS); the Pan American Operation (OPA); The Pacific Alliance; the Latin American Parliament (PARLATINO); the Rio Group; and lastly, the Community and Union of South American Nations (UNASUR ${ }^{\star}$ ).

The second dictionary aims to measure the broadest and most abstract references to regional and hemispheric cooperation and integration. For this, we counted the number of mentions using simple and direct criteria, leaving no room for ambiguity. Thus, the formula we followed was based on the use of the terms 'integration' or 'cooperation' - be it regional, hemispheric, South American or Latin American.

With regards to the qualitative analysis, the following approach was chosen: a) We used the terms of the dictionary of regional projects; b) We selected the 30 words that appear around the name and/or acronyms of each project via Keyword in Context (KWIC); c) We did a careful reading of the texts, in which we categorized the meaning of each phrase; d) We determined which connotation prevailed in the case of each project.

Both the quantitative and the qualitative analysis were conducted using R and RStudio and packages such as Tidyverse, Quanteda and RQDA. We chose these because they are public and free and, thus, value transparency and replicability. For this same reason, all files, documents, commands and computational procedures are available in their entirety 
on a platform that allows for easy downloading. We now turn to the results that were obtained.

\section{Results}

Graph 2 shows the frequency with which each regional project was mentioned in Brazilian speeches to the UN.

Graph 2 - Frequency of mentions of regional projects at UN Assembly Sessions

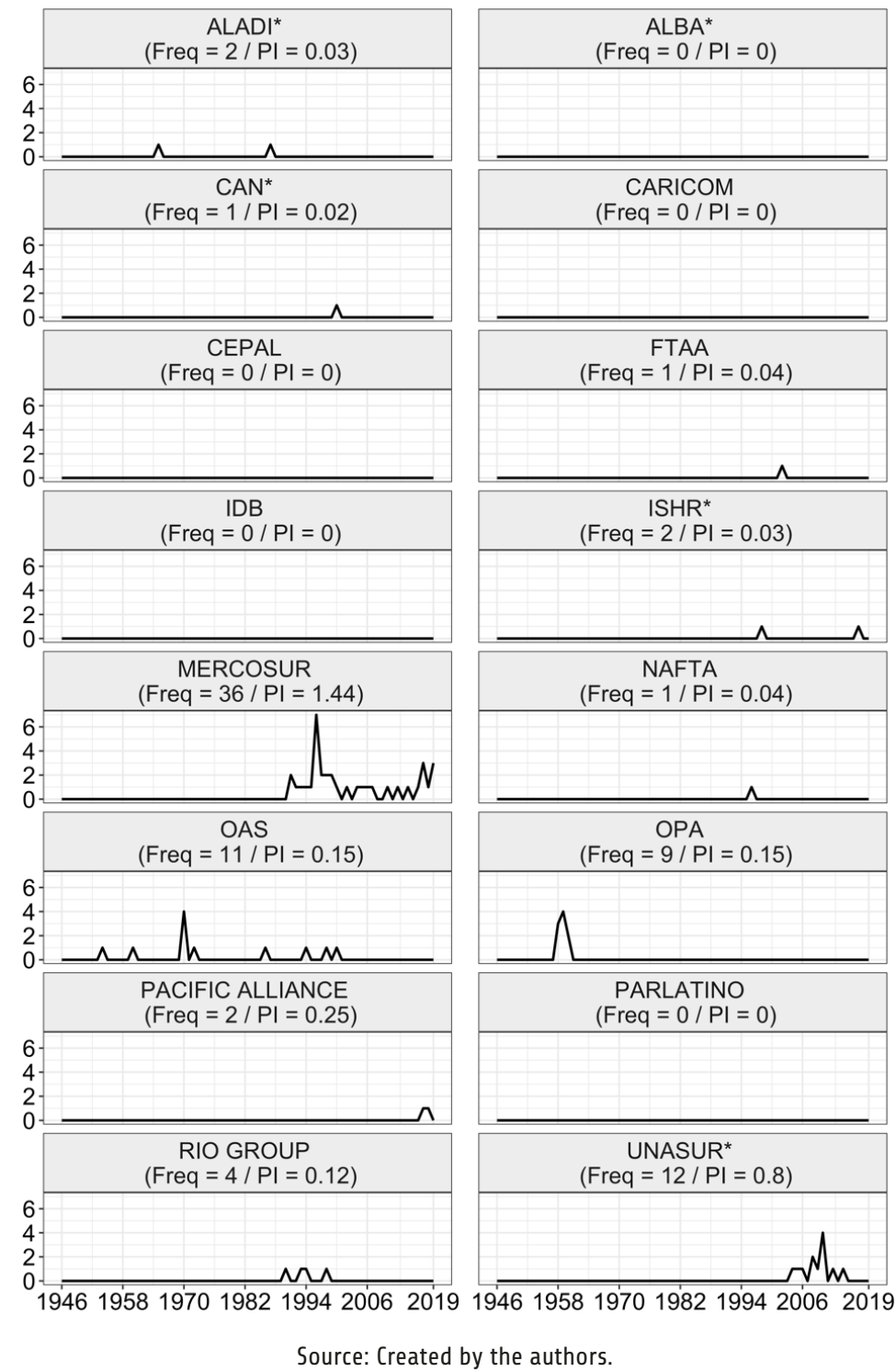


Graph 2 presents several pieces of relevant information. First, if we look only at the absolute frequency of mentions, we realize that MERCOSUR was, by far, the bloc that Brazil was most interested in mentioning at UN meetings. No other project has received as many mentions. Thus, from its creation in the early 1990s up until 2019, Brazilian diplomacy has rarely failed to bring the bloc to the forefront of the political debates. In particular, MERCOSUR was mentioned seven times in 1996 (the highest point in the distribution).

Furthermore, even if we look at the prevalence indicator (PI) created to control the total number of mentions for the duration of the regional project, we can see that MERCOSUR is the only one with a value greater than 1 . UNASUR ${ }^{*}$ is the next highest, with a value of 0.8 - which is still significant, considering its recent existence as opposed to MERCOSUR.

Next, UNASUR ${ }^{\star}$ also performs impressively. As we have said, despite being the second most recent bloc (after the Pacific Alliance), it received much more mentions than any other regional and hemispheric project. Then, we have the OAS, which stood out as the most cited hemispheric project in Brazilian speeches. However, it is worth considering that, when we control the mentions for the lifespan of the project, the OAS loses out, being overshadowed by other projects such as the Pacific Alliance, a much more recent bloc.

Other projects that merited attention were the Rio Group and the OPA, also grouped within the top five mentioned projects in Brazilian speeches to the UN. In general, however, the graph is more notable for the silences. We expected that entities like CEPAL, $\mathrm{ALBA}^{*}$, PARLATINO, or even the Inter-American Human Rights System would be incorporated into Brazilian speeches more frequently than they in fact were. American regional projects did not occupy a prominent place in the structure of Brazilian discourse in the multilateral setting of the UN General Assembly. This is a fact.

Judging only by the number of citations attributed to each of the projects, it is apparent that American regionalism occupies a residual space in the Brazilian rhetoric at the UN. For purposes of comparison, we present, in Table 1, the frequency of references to regionalism in a broader and more abstract sense.

Table 1 - Frequency of mentions of regionalism in Brazilian UN Speeches

\begin{tabular}{ll}
\hline TERM & FREQUENCY \\
\hline Cooperation & 317 \\
\hline Hemispheric Cooperation & 0 \\
\hline Latin American Cooperation & 0 \\
\hline South American Cooperation & 0 \\
\hline Regional Cooperation & 1 \\
\hline Integration & 74 \\
\hline Hemispheric Integration & 0 \\
\hline Latin American Integration & 2 \\
\hline South American Integration & 2 \\
\hline Regional Integration & 5 \\
\hline
\end{tabular}


Upon looking at how often Brazilian diplomacy mentioned regional, hemispheric, South American and/or Latin American cooperation or integration, it is possible to see that there are only 10 mentions in total, out of a total of 391 general references to cooperation and integration (as an empty signifier). We can likewise see that the terms 'South American' and 'Latin American' were not associated with one another and acquired different connotations at the UN. With regard to the theme of cooperation, there were no mentions for each, that is, zero; conversely, relating to integration, there were two mentions for each. In this sense, it is curious to note that, however seldom South America and Latin America appear in this institutional setting, should they be mentioned at all, they come framed under the topic of integration.

In any case, it is easy to see that Brazilian diplomatic actors were more interested in broad and undirected rhetorical manoeuvre than in concrete pronouncements. Notwithstanding, we can only properly evaluate this hypothesis by using qualitative discourse analysis. Yet before doing so, we should nevertheless identify some conditions and characteristics relating to the ways different speakers mentioned regionalism, as shown in Graph 3.

Graph 3 - Frequency of mentions of regional projects by different speakers

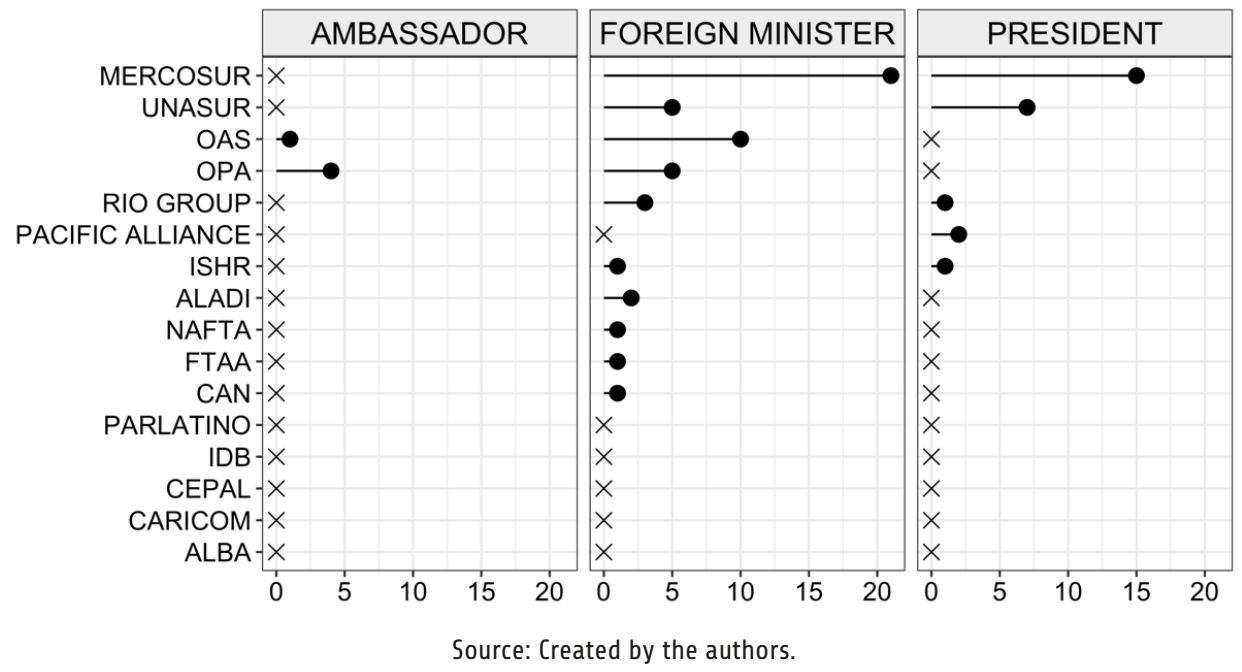

The Xs identify projects that received no mentions, whereas those that were mentioned at least once are represented by a dot. We can see that ambassadors were least likely to mention any specific type of regionalism, with only the OAS and OPA cited. In the case of Foreign Secretaries, a greater variety of projects is cited. MERCOSUR stands out, given that, out of a total of 36 mentions of this project, 21 were made by Brazilian Foreign Secretaries. The OAS was also frequently cited. In this case, it is curious to see that the OAS was mentioned only by professional diplomats and entirely ignored by presidents. The OPA and the Rio Group also stood out in speeches addressed by ambassadors. As for the presidents, they prioritized MERCOSUR and UNASUR ${ }^{\star}$. In the case of the latter, 
out of a total of 12 mentions, 7 were observed in presidential speeches and 5 in speeches delivered by Foreign Secretaries.

Having seen who the actors were and how often they cited each of the regional projects analysed here, we must also do the same for references to regionalism as an empty and abstract signifier, as shown in Graph 4.

Graph 4 - Frequency of mentions of abstract regionalism by different speakers

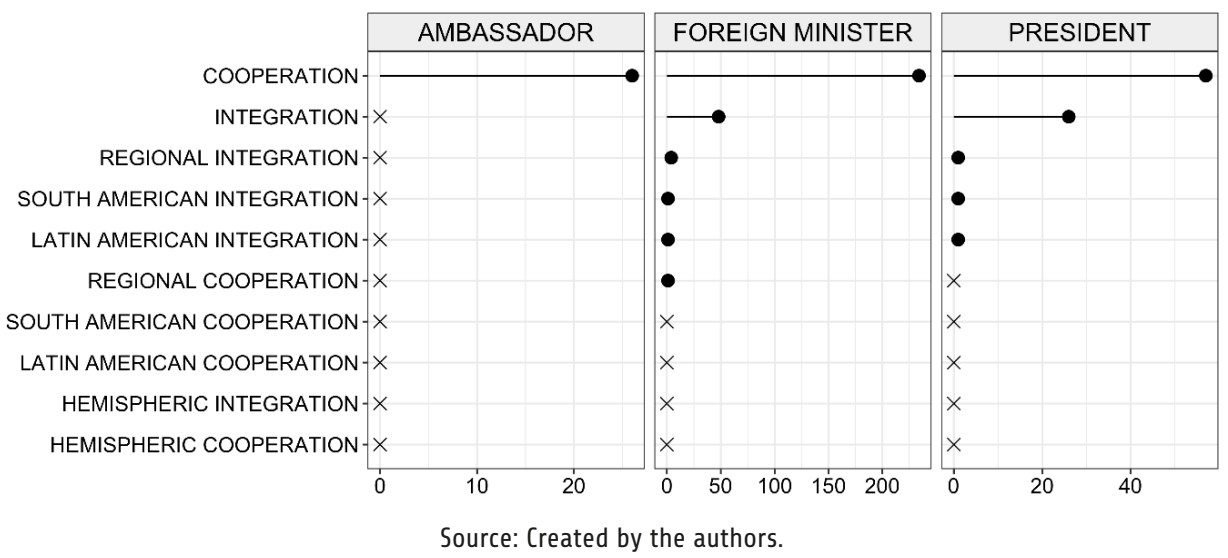

A curious pattern can be identified in the Graph above: all three types of speakers, namely ambassadors, foreign secretaries and presidents, constantly mentioned cooperation, yet as an abstraction. The concept of integration, in turn, was the second most frequently cited, only in a much less extraordinary way. Apparently, then, in speeches of UN ordinary meetings, both presidential diplomacy and professional diplomacy were aligned in quantitative terms.

It is also striking that the ambassadors were not, at any point during the 73 years analysed, interested in speaking in terms of integration or in discussing cooperation based on labels more explicitly associated with the regional, American or hemispheric spheres. These are mentioned by the foreign secretaries, but even so, they discuss integration to a lesser extent than cooperation. Additionally, we also can see that the labels South America and Latin America always appear linked to the theme of integration.

Furthermore, when cross-referencing and comparing this pattern with the one seen in Table 1, the questioning that arises refers to what the terms 'cooperation' and 'integration' actually refer to in the diplomatic speeches addressed to the UN General Assembly. If diplomats are not, as a rule, associating these terms with the regionalism developed on the American continent, for what purposes and realities is this vocabulary being used? In an attempt to answer this question, Graph 5 counts the most repeated expressions linked to the two words under analysis. 
Graph 5 - The most repeated expressions on cooperation and integration
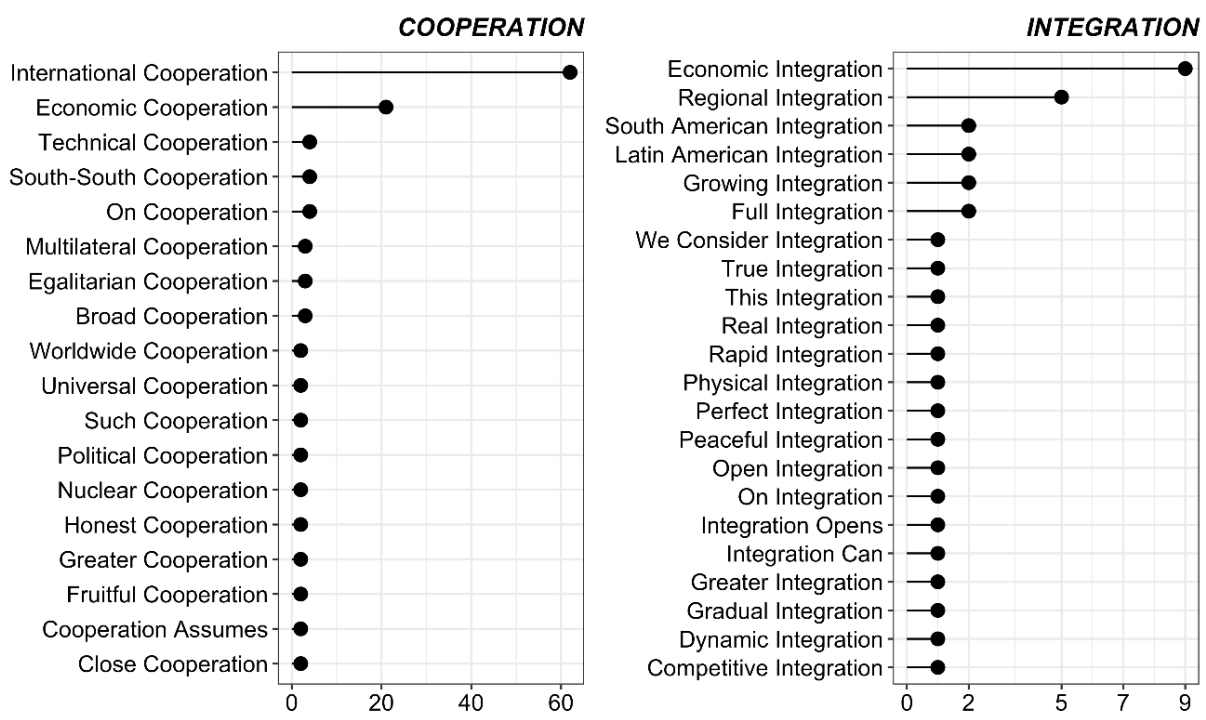

Source: Created by the authors.

Before comparing the results of each graph in the figure, it is important to point out that the scales are different: while the cooperation side ranges from zero to 60, the integration side spans from zero to nine. This indicates that, in the Brazilian diplomatic discourse analysed here, the first concept has a broader scope than the second. This, in turn, seems intrinsic to the very nature of the concepts and objects to which they refer.

As such, we can see that both terms are used in two distinct ways: one term that is more connected with adjective labels and another term, more associated with reference forms. Thus, for the first category, we see that positive rhetorical constructions are associated both with the concepts of cooperation (egalitarian cooperation, broad cooperation, frank cooperation, fruitful cooperation, close cooperation), and of integration (increasing integration, full integration, real integration, true integration, rapid integration, perfect integration, peaceful integration, integration can, gradual integration, dynamic integration).

For the second category - of concepts as a form of reference - cases in which more direct and even more technical constructions were observed. This prevails both for the case of integration (economic integration, regional integration, South American integration, Latin American integration, physical integration, open integration) and for cooperation (international cooperation, economic cooperation, technical cooperation, south-south cooperation, multilateral cooperation, world cooperation, nuclear cooperation, political cooperation).

Finally, let us look at some specificities that were revealed by our textual, qualitative and critical analysis. As already shown, the Andean Community of Nations (CAN ${ }^{\star}$ ) has only been mentioned once. This mention was made on September 12, 2000 by the then Brazilian Foreign Secretary Luiz Felipe Lampreia when referring to the construction of 
greater commercial cooperation between the Latin American regional blocs in order to form a free trade area between the MERCOSUR and the CAN. We can then see the predominance of commercial and pragmatic considerations in the adoption of this discourse.

In the case of the FTAA, the only reference made was on September 12, 2002 by then Foreign Secretary Celso Lafer as he spoke about Brazil's commitment to the negotiations taking place between the European Union and certain Latin American states in the process of shaping the so-called Free Trade Area of the Americas. Again, we highlight the purely commercial association present in this quote.

As for ALADI*, two mentions were made. The first occurred in 1965 - hence within the scope of ALALC - by the then Foreign Secretary Vasco Leitão da Cunha. He affirmed that Brazil placed great hope in ALALC, which, according to him, had already generated several important results in its first few years of existence. In 1987, Foreign Secretary Roberto Costa de Abreu Sodré mentioned ALADI once again. However, this time, the bloc neither played a significant role nor had such positive connotations, since it was merely listed alongside other projects, such as SELA, OLADE, and the Cartagena Consensus.

Thirty-three references are made to MERCOSUR. Of course, encompassing all mentions of the South American bloc in a single, concise interpretation is not an easy task. However, it is possible to affirm that Brazilian discourse around the MERCOSUR, throughout the period of all the years analysed, appears to be both maximalist and empty. It is maximalist in that it is apparently possible to fit an infinite constellation of rhetorical meanings and signs within the signifier 'MERCOSUR.' The bloc is seen as a fundamental tool for peace, stability, unity, strength, integration, identity construction, openness to trade and social advancement both for the countries involved and for Brazilian citizens. For this same reason, it is empty to the extent that the rhetoric for the bloc has become increasingly flexible, to the point of resembling the Laclauian concept of an 'empty signifier' (Laclau 2016).

NAFTA was also only mentioned once, in 1996, by Luiz Felipe Lampreia, when citing several regional blocs in the international order that were in process of formation. The mention did not attract particular attention and was not addressed individually; as such, it does not register as significant in the discursive structure of Brazilian diplomacy at the UN General Assembly.

The OAS has been brought up in discourse eleven times. Most specifically, it was predominantly focused on how to deal with democratic ruptures and threats such as transnational crime, international drug trafficking, terrorism and political crises, in addition to several references to the OAS Charter, social progress and the fight against racism, as well as the need to ensure the rights of minorities. There were also brief references to the existence of the OAS and the relationship between its principles and the guidelines of the BFP itself.

The Pacific Alliance, albeit recent, has been mentioned twice. The first time was in 2017, and the second in 2018, both brought up by President Michel Temer. In both instances, the mention occurred in the context of praising efforts to expand cooperation 
between MERCOSUR and the Pacific Alliance, in order to enable the promotion of even greater trade liberalization.

The UNASUR has been cited a total of 12 times. This demonstrates the importance of South America as a regional horizon of BFP, with the experience of UNASUR representing an institutional concretisation of this. UNASUR was cited several times as a historic milestone, and as the first independent meeting of all South American countries. The organisation acquires a connotation, and is spoken of, as another means for promoting democracy, cooperative ties, and fair and sustainable economic growth in the region.

Thus, Brazilian rhetoric at the UN regarding UNASUR as an integration project emphasised its positive results, highlighting its effectiveness in promoting peace, prosperity and the strengthening of the subcontinent. As we know, however, along with a few other South American leaders, Bolsonaro decided to leave the UNASUR in an effort to dismantle the bloc and create the PROSUL, mentioned once in the speeches. Despite that effort, there have been no rhetorical signals in UN speeches by 2019 that significantly alter the previous connotations given to UNASUR. So far, Bolsonaro has opted for silence instead of rhetorical iconoclasm.

As we have seen, Brazil has developed a pattern of presenting regionalism on the American continent in a way we consider to be a low visibility one. Even MERCOSUR, the most regularly cited body in diplomatic speeches, did not appear as often as we would otherwise have expected. Nonetheless, it is curious how the other projects were practically invisible at the UN level. Furthermore, it is interesting to identify how the rhetoric used to refer to the MERCOSUR has been, historically, extremely flexible to the point of almost reaching a status that renders it empty.

Thus, this article contributes with a number of important findings on the rhetorical structure of Brazilian diplomacy at the UN. One, in particular, stands out. By connecting the earlier theoretical discussion on the history of regionalism in the American continent and the role of regional integration sustained by the BFP with the results we find here, we can say that Brazil exhibits a very pragmatic and economical rhetorical-discursive pattern. To sum up, when reflecting on our results as a whole, along with the theory, it seems plausible to conclude that, with the exception of the projects that the country itself heads/ leads (MERCOSUR, UNASUR, and OPA), American regional projects are not part of the constellation presented by Brazilian diplomacy at annual UN meetings.

Apparently, for an American regionalism to be included in the Brazilian rhetoric space at the UN General Assembly, it must meet certain criteria. The first is that if of hemispheric scope, it must be associated with the OAS. The second is that if of regional scope, it is essential that it is designed by Brazil itself in the first place. Furthermore, other variables also appear to be important, even though their impact is still unclear in the analysis. Time, for example, seems to play a key role. Projects that emerged after Brazilian democratization are more likely to be cited at the UN, which explains why the Pacific Alliance has the third highest score. At the same time, the ideological inclination of the speaker can also be important. This also helps to explain the case of the Pacific Alliance, constantly mentioned by Michel Temer. 
In conclusion, it is important for future studies to seek to compare these and other mechanisms so that the necessity and sufficiency of these conditions can be better understood, as well as the interactions between them and several other possible variables. Only then can we better comprehend the reasons behind Brazilian diplomatic discourse, be it at the UN or in any other institutional space. This article has taken an important step along this path. At this point, moving forward is just as possible as necessary.

\section{Final considerations}

In this article, we have aimed to explore and describe certain particularities of the rhetoric constructed by Brazilian diplomacy in multilateral settings on the theme of American regionalism and its projects and values. Indeed, we were inspired by the existing literature on Latin American regional integration. According to some of the authors discussed here, rhetoric has a significant influence on the performance of American regional projects, both in a positive and in a negative way. Thus, we demonstrate that there is no shortage of theoretical justification for taking political speeches seriously to attempt to discover patterns and argumentative structures within them that sediment principles, silences, omissions and/or priorities.

Based on this, we collected all Brazilian speeches delivered during the annual General Sessions of the UN General Assembly between 1946 and 2019 and adopted techniques such as content analysis and discourse analysis to identify possible rhetorical constellations. Despite the limitations of the inferential logic of these techniques, it was possible to reveal that the Brazilian diplomatic actors opted for a more flexible, abstract, and hollow discursive structure. Apparently, they avoided mentioning specific American regional projects, talked extensively about cooperation and integration (as a value or empty signifier), and seldom mentioned the limits and possibilities of the actual regional arrangements in formation.

As for future research agendas, this article opens up space for a range of possible future paths and perspectives. Firstly, it is urgent that its results be replicated, checked, and compared by various quantitative and qualitative techniques; in particular, through discourse analysis, text mining, and machine learning. Only then will it be possible to refine the findings of this research and measure their plausibility in a more appropriate way.

Secondly, it is essential to apply the approach to new speeches by adding variables, including different actors and contexts to enable a comparison between the discursive characteristics of Brazilian diplomacy in different institutional environments. To this end, it would be interesting to collect, analyse and monitor the discursive trends of Brazilian diplomacy in international institutions such as the WTO, WHO, and the OAS, and to compare them with speeches delivered in different regional institutions. After all, if Brazilian diplomacy speaks little of regional integration at the UN, in which institutional spaces does it give visibility to these issues, if any?

Likewise, it is urgent that the descriptive and exploratory analysis carried out here be expanded and deepened in order to uncover a broader process of causal inference via 
the comparison of causal dynamics, conditions, and mechanisms. The results found here should be adapted to research designs that involve techniques such as regression analysis and qualitative comparative analysis (QCA).

A fourth point is the need for a more critical and qualitative assessment of the aspects of rupture and continuity observed in the pronouncements of each president and diplomat. We need to better understand the specific attributes of the professional and traditional diplomacy, as well as in what ways, and to what extent, these differ from one another. That way, it would be possible to better understand how UNASUR and its dismantling, and regionalism, more broadly, is likely to be presented and reframed at the UN. In short, it is necessary to advance research that seeks to describe, systematise and scrutinise the Brazilian diplomatic discourse, as well as its emphases and silences in terms of how the country's image and international insertion are strategically constructed in official narratives.

\section{Notes}

1 Replication data can be found here: https://doi.org/10.7910/DVN/9WLKRO.

2 Asterisks were used to indicate that the regional project is broadly construed. Therefore, it was measured not only by its current name and/or acronym but also by its previous references or forerunner projects. Thus, the asterisk in ALADI* is to show that both the Latin American Free Trade Association and the Latin American Association were considered. Likewise, the asterisk in ALBA* is there to indicate that both the Bolivarian Alliance for the Peoples of Our America and the Bolivarian Alternative for the Americas were counted as one label. This rule also applies to $\mathrm{CAN}^{\star}$ (the Andean Pact and the Andean Community of Nations), ISHR ${ }^{\star}$ (the Inter-American Court and the Commission on Human Rights), and UNASUR (the Community and the Union of South American Nations).

\section{References}

Amado, A and M L R Mollo. 2004. 'Ortodoxia e heterodoxia na discussão sobre integração regional: a origem do pensamento da CEPAL e seus desenvolvimentos posteriors.' Estudos Econômicos 34 (1): 129-156.

Arbilla, J M. 2000. 'Arranjos institucionais e mudança conceitual nas políticas externas argentina e brasileira (1989-1994).' Contexto internacional 22 (2): 337-385.

Bethell, L. 2009. 'O Brasil e a ideia de América Latina em perspectiva histórica.' Revista Estudos Históricos 22 (44): 289-2321.

Briceño-Ruiz, J. 2018. 'Times of Change in Latin American Regionalism.' Contexto Internacional 40 (3): 573-194.

Briceño-Ruiz, J and A R Puntigliano. 2017. Brazil and Latin America: Between the Separation and Integration Paths. Lanham: Lexington Books.

Burges, S. 2006. 'Without sticks or carrots: Brazilian leadership in South America during the Cardoso Era, 1992-2003.' Bulletin of Latin American Research 25 (1): 23-42.

2008. 'Consensual hegemony: theorizing Brazilian foreign policy after the Cold War.' International relations 22 (1): 65-84. 2009. Brazilian Foreign Policy after the Cold War. Florida: University Press of Florida. 
Cervo, A L and A C Lessa. 2014. 'O declínio: inserção internacional do Brasil (2011-2014).' Revista Brasileira de Política Internacional 57 (2): 133-151.

Corrêa, L F de S. 2012. O Brasil nas Nações Unidas, 1946-2011. Brasília: Fundação Alexandre de Gusmão.

Couto, L F. 2007. 'O horizonte regional do Brasil e a construção da América do Sul.' Revista Brasileira de Política Internacional 50 (1): 159-176.

Dabène, O. 2009. The Politics of Regional Integration in Latin America: Theoretical and Comparative Explorations. New York: Palgrave Macmilllan.

Fitjar, R D. 2005. 'Measuring regionalism: content analysis and the case of Rogaland in Norway' Regional \& Federal Studies 15 (1): 59-73.

Gardini, G L. 2015. 'Towards modular regionalism: the proliferation of Latin American cooperation.' Revista Brasileira de Politica Internacional 58 (1): 210-229.

Gardini, G L and M H T de Almeida (eds). 2017. Foreign Policy Responses to the Rise of Brazil: Balancing Power in Emerging States. London: Palgrave Macmillan.

Hurrell, A. 1992. 'Latin America in the New World Order: a regional bloc of the Americas?' International Affairs 68 (1): 121-139.

Hurrell, A and L L Fawcett. 1998. Regionalism in World Politics: Regional Organization and International Order. Oxford: Oxford University Press.

Jenne, N. 2013. 'Whither the push and pull for integration: taking stock of Latin America's declaratory regionalism.' Robert Schuman Centre for Advanced Studies Research Paper 2013/82.

Jenne, N, L L Schenoni and F Urdinez. 2017. 'Of words and deeds: Latin American declaratory regionalism, 1994-2014.' Cambridge Review of International Affairs 30 (2-3): 195-215.

Laclau, E. 2016. La Razón Populista. Cidade do México: Fondo de cultura Económica.

Legler, T. 2013. 'Post-hegemonic regionalism and sovereignty in Latin America: optimists, skeptics, and an emerging research agenda.' Contexto Internacional 35 (2): 325-352.

Long, T. 2015. Latin America Confronts the United States: Asymmetry and Influence. Cambridge: Cambridge University Press.

MacDonald, L and A Rückert. 2009. Post-neoliberalism in the Americas. New York: Palgrave Macmillan.

Malamud, A. 2011. 'A leader without followers? the growing divergence between the regional and global performance of Brazilian foreign policy'. Latin American Politics and Society 53 (3): 1-24.

Malamud, A and G L Gardini. 2012. 'Has regionalism peaked? the Latin American quagmire and its lessons.' The International Spectator 47 (1): 116-133.

Mares, D R and H A Trinkunas. 2016. Aspirational Power: Brazil on the Long Road to Global Influence. Washington, DC: Brookings Institution Press.

Meunier, I and M de A Medeiros. 2013. 'Construindo a América do Sul: identidades e interesses na formação discursiva da Unasul.' Dados 56 (3): 673-712.

Medeiros, M de A and C F Dri. 2013. 'Which Brazilian policy for regionalism? Discourse and institutional development in Mercosur.' Estudios internacionales 45: 41-61.

Montecinos, V. 1996. 'Ceremonial regionalism, institutions and integration in the Americas' Studies in comparative international development 31 (2): 110-123. 
Nolte, D and N M Comini. 2016. 'UNASUR: regional pluralism as a strategic outcome.' Contexto internacional 38 (2): 545-565.

Phillips, N. 2003. 'Hemispheric integration and subregionalism in the Americas.' International Affairs 79 (2): 327-349.

Pinheiro, L. 2004. Política Externa Brasileira: 1889-2002. Rio de Janeiro: Zahar.

Riggirozzi, P. 2012. 'Region, regionness and regionalism in Latin America: towards a new synthesis.' New Political Economy 17 (4): 421-443.

Riggirozzi, P and D Tussie (eds). 2012. The Rise of Post-Hegemonic Regionalism: The Case of Latin America. Dordrecht: Springer.

Santos, L C V G. 2005. 'A América do Sul no discurso diplomático brasileiro.' Revista Brasileira de Política Internacional 48 (2): 185-204.

Saraiva, M G. 2014. 'The Brazilian Soft Power Tradition.' Current History 113 (760): 64-69.

Spektor, M. 2010. 'Ideias de ativismo regional: a transformação das leituras brasileiras da região' Revista Brasileira de Política Internacional 53 (1): 25-44.

Stuenkel, O and M M Taylor. 2015. Brazil on the Global Stage: Power, Ideas, and the Liberal International Order. New York: Palgrave Macmilllan.

Tussie, D. 2009. 'Latin America: contrasting motivations for regional projects.' Review of International Studies 35 (S1): 169-188.

Vilela, E and P Neiva. 2011. 'Temas e regiões nas políticas externas de Lula e Fernando Henrique: comparação do discurso dos dois presidents.' Revista Brasileira de Política Internacional 54 (2): 70-96.

Weber, R P. 1990. Basic Content Analysis. California: Sage.

Wehner, L E. 2015. 'Role expectations as foreign policy: South American secondary powers' expectations of Brazil as a regional power.' Foreign Policy Analysis 11 (4): 435-455.

\section{Acknowledgements}

This work was carried out with support from the Brazilian Conselho Nacional de Desenvolvimento Científico e Tecnológico (CNPq) (National Council for Scientific and Technological Development) and the Brazilian Coordenação de Aperfeiçoamento de Pessoal de Nível Superior (CAPES) (Coordination for the Improvement of Higher Education Personnel), Financing Code 001. The authors acknowledge the comments and suggestions made by the anonymous reviewers, as well as by the journal's editorial team.

\section{About the authors}

Felipe Ferreira de Oliveira Rocha (CNPq scholarship) is a Ph.D. student in Political Science at the Federal University of Pernambuco (UFPE). He holds a Master's degree (2017) in Political Science from the same institution and a Bachelor's degree (2015) in International Relations from the Federal University of Sergipe (UFS). In his Master's dissertation, he analysed how frequent were the concepts of Latin America and South America in the discourse of Brazilian foreign policymakers. Currently, in his Ph.D. thesis, he aims to explore, describe, and compare the thematic emphases of Brazilian Presidents 
and Foreign Ministers (1995-2019). His research interests cover Brazilian foreign policy, foreign policy analysis, and data analysis. Website: feliperocha.info. Lattes: http://lattes. cnpq.br/5112574032057435.

Marcelo de Almeida Medeiros received his Ph.D. in Political Science from the Institut d'Études Politiques de Grenoble (1997) and his Habilitation Thesis from the Institut d'Études Politiques de Paris - Sciences Po (2010). He is a Full Professor of Comparative International Politics at the Federal University of Pernambuco (UFPE) in Recife-Brazil, a PQ-1C Research Fellow of the National Council for Scientific and Technological Development - CNPq (Brasília - Brazil), and Leader of the Center for Comparative Policy and International Relations Studies - NEPI/UFPE/CNPq. His research interests cover International Politics and Comparative Government, especially the following topics: Mercosur, Brazilian foreign policy, European Union, French foreign policy, institutions, governance and democracy. Lattes: http://lattes.cnpq.br/2986573450358373.

\title{
Regionalismo Americano e Discurso Diplomático Brasileiro (1946-2019)
}

\begin{abstract}
Resumo: Neste artigo, analisamos o conteúdo dos discursos proferidos por Presidentes, Chanceleres e Embaixadores brasileiros nas Sessões Ordinárias anuais da Assembleia Geral das Nações Unidas entre 1946 e 2019. O objetivo principal é descobrir com que frequência e em que circunstâncias os diplomatas brasileiros fizeram menção ao regionalismo americano, seja em relação a projetos específicos, seja em conceitos abstratos de integração e cooperação regional. Com base nessa análise, destacamos a grande importância dada ao MERCOSUL (e, em menor medida, à UNASUL) em detrimento de outros regionalismos, bem como a preferência dos diplomatas brasileiros por uma abordagem discursiva flexível, discreta, abstrata e de baixo custo. Em suma, a cooperação e a integração têm sido frequentemente discutidas, mas pouca atenção tem sido dada aos limites e possibilidades de cada projeto em construção.
\end{abstract}

Palavras-chave: integração regional; Política Externa Brasileira; Análise de Política Externa; análise de conteúdo; diplomacia; Nações Unidas.

Received on 5 December 2019, and approved for publication on 15 September 2020. 